Arkivoc

Free to Authors and Readers
A Platinum Open Access Journal for Organic Chemistry

Paper

DOAJ Seal
Arkivoc 2021, part ii, 85-98

\title{
Reactions of quinine with 2-chloro-4,6-dimethoxy-1,3,5-triazine
}

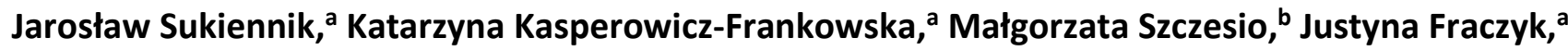 \\ Beata Kolesinska ${ }^{a}$ and Zbigniew J. Kaminski* \\ a Institute of Organic Chemistry, Lodz University of Technology, Lodz, Poland \\ ${ }^{b}$ Institute of General and Ecological Chemistry, Lodz University of Technology, Lodz, Poland \\ Email: zbigniew.kaminski@p.lodz.pl
}

In Honor of Prof. Zbigniew Czarnocki on the occasion of his $66^{\text {th }}$ anniversary

Received 09-12-2020

Accepted 11-09-2020

Published on line 11-18-2020

\section{Abstract}

Quinine reacts with 2-chloro-4,6-dimethoxy-1,3,5-triazine (CDMT) via a multistage process leading to destruction of the quinuclidine fragment and attachment of two triazinyl substituents. In the first, reversible stage, CDMT reacts with the aromatic nitrogen of the quinoline, followed by the slow migration of triazine moiety on the bridgehead nitrogen atom of quinuclidine. The bicyclic system, after quaternization with CDMT, was opened by privileged attack of nucleophilic chloride on methylene carbon in the bridge substituted with vinyl group. In the final stage the second 4,6-dimethoxy-1,3,5-triazin-2-yl moiety was attached to the hydroxy group. The product structure was confirmed by X-ray crystallographic measurements, MS, ${ }^{1} \mathrm{H}$ and ${ }^{13} \mathrm{C} N M R$, and IR spectroscopy.<smiles>[CH][C@]1([C@H](Oc2nc(OC)nc(OC)n2)c2ccnc3ccc(OC)cc23)C[C@@H]([C@H](C=C)CCl)CCN1c1nc(OC)nc(OC)n1</smiles>

Keywords: Ring opening, quaternization, 4,5-dimethoxy-1,3,5-triazin-2-yl ammonium chloride, aromatic nucleophilic substitution 


\section{Introduction}

Two pairs of pseudo-enantiomeric forms known as quinine-quinidine and cynchonine-cynchonidine, isolated from cinchona species, made them exceedingly attractive components in numerous stereoselective processes. ${ }^{1-3}$ Their synthetic potential was also noticed in our attempts to design and develop traceless, predictable coupling reagents dedicated to the synthesis of enantiomerically homogeneous peptides directly from racemic $\mathrm{N}$-protected amino-acids. ${ }^{4,5}$ This new group of enantioselective reagents consists of chiral components and the classical achiral coupling reagent. In the case of the enantioselective, predictable coupling reagent, the chiral component participates only in the enantioselective activation of the carboxylic group. Its departure after this stage affords carboxylic component activated by the known, achiral coupling reagent. ${ }^{6}$ Thus, optimized coupling conditions remain intact and independent on the structure of the chiral counterpart of the predictable coupling reagent. Moreover, configuration and enantiomeric enrichment of the given pair of carboxylic substrate and chiral component also remain the same in all the subsequent coupling stages and can be established easily in a single, model experiment.

In practice, enantioselective coupling of two equivalents of racemic $\mathrm{N}$-protected amino acids by means of achiral triazine based coupling reagent and strychnine or brucine used as chiral component gave peptides with very high yield precisely predictable configuration and enantiomeric enrichment up to ee $99 \%$. Under such conditions, Kagan's coefficient exceeded 100 in favorable cases. Nevertheless, brucine and strychnine are affordable in one configuration only, but one can presume that the application of the above mentioned pseudo-enantiomeric cinchona alkaloids would pave the way to the activation of any desired enantiomer.

Unpredictably, attempts to perform enantioselective peptide syntheses in the presence of quinine and/or quinidine failed to yield peptide products, suggesting an unknown process leading to the degradation of the alkaloids. To identify the structures obtained in this unprofitable transformation, the reaction of quinine (1) with 2-chloro-4,6-dimethoxy-1,3,5-triazine (CDMT) (2) was studied.

\section{Results and Discussion}

\section{Synthesis}

In the quinine molecule, there are two tertiary nitrogen atoms prone to quaternization when treated with CDMT (2). Their usefulness in enantioselective syntheses is diverse. The bridgehead aliphatic nitrogen of the substituted quinuclidine fragment is chiral and its high expediency to act as chiral selector in enantioselective reactions is expected. On the other hand, the aromatic nitrogen of quinoline is located far away from the chirality center of quinine and its effectiveness as enantioselector is problematic. Therefore, to identify the more reactive one, quinine (1) was treated with equimolar amounts of CDMT (2) (Scheme 1). Unexpectedly, instead product $\mathbf{3}$ (path A) or $\mathbf{4}$ (path B) a mixture of other products was obtained. 


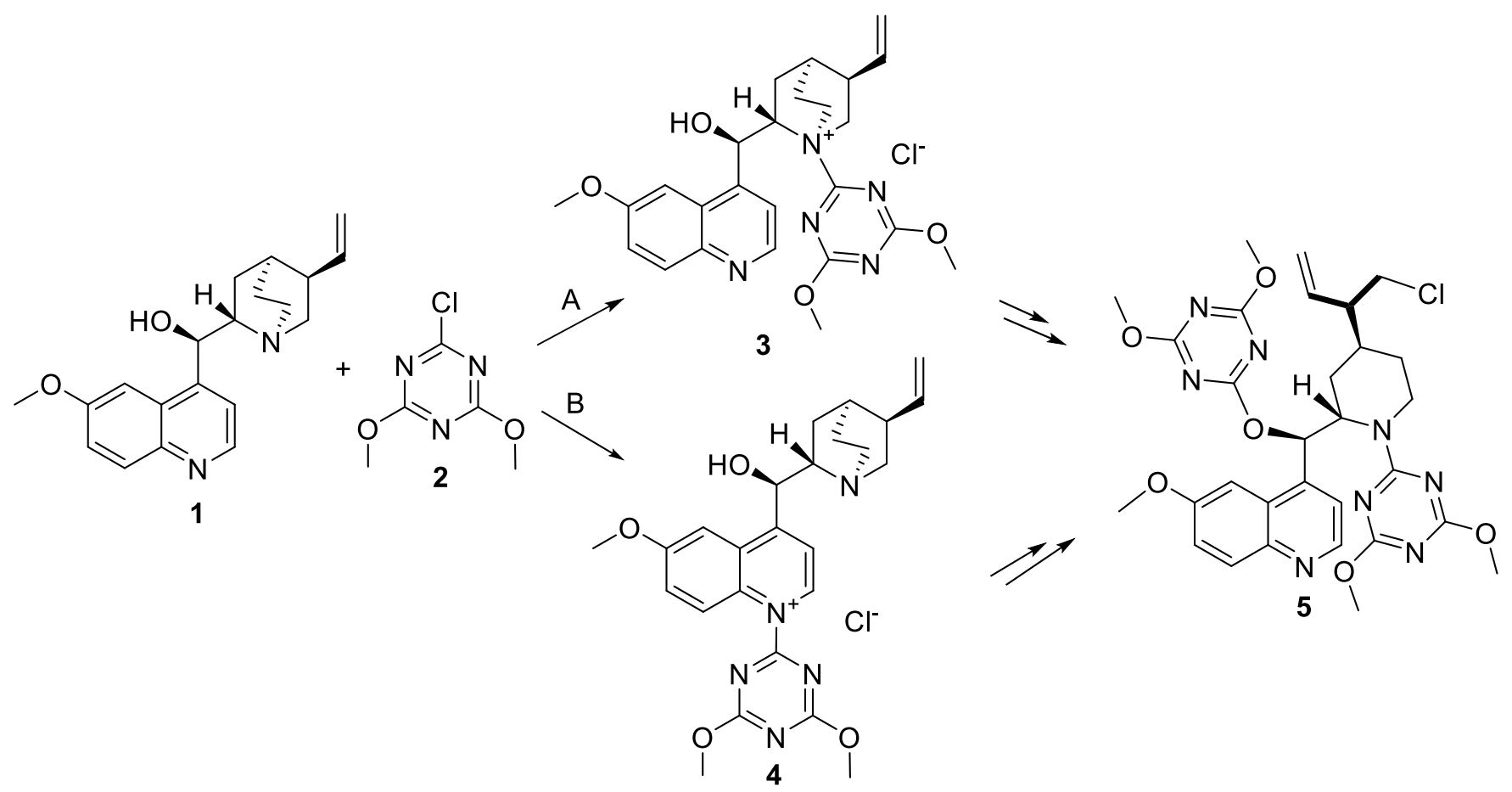

Scheme 1. Two possible pathway of reaction quinine (1) with CDMT (2).

In the solution of the equimolar mixture of both substrates a trace of unreacted CDMT (2) was identified even after an overnight reaction at room temperature. To complete the consumption of CDMT (2), an additional $24 \mathrm{~h}$ heating in boiling dichloromethane was necessary. The analysis of the mixture obtained by TLC showed the presence of one major and four minor products, all of them UV active. Major component $\mathbf{5}$ was isolated by silica gel column chromatography. Its purity determined by HPLC was further substantially improved by recrystallization from hexane/EtOAc enabling structural studies with the use of ${ }^{1} \mathrm{H},{ }^{13} \mathrm{C} \mathrm{NMR,} \mathrm{MS,}$ IR and X-ray crystallography.

\section{Crystal structures determination}

A single crystal of compound 5 suitable for X-ray diffraction was obtained from $n$-heptane/ethyl acetate solutions by slow evaporation of the solvents at room temperature.

The similar values of the C51-N46, C51-N52 and C51-N56 bond lengths, amounting to 1.352(2), 1.350(2) and $1.350(2) \AA$, respectively, indicate the presence of the conjugation of the nitrogen atom of the piperidine ring with the triazine. The structure contains only weak $\mathrm{C}-\mathrm{H} \cdots \mathrm{O}$ and $\mathrm{C}-\mathrm{H} \cdots \mathrm{N}$ hydrogen bonds (Table 2), which stabilize the packing of molecules (Figure 2). Additionally, there are stacking interactions in the structure (distance $3.36 \AA ̊$, Figure 4). 


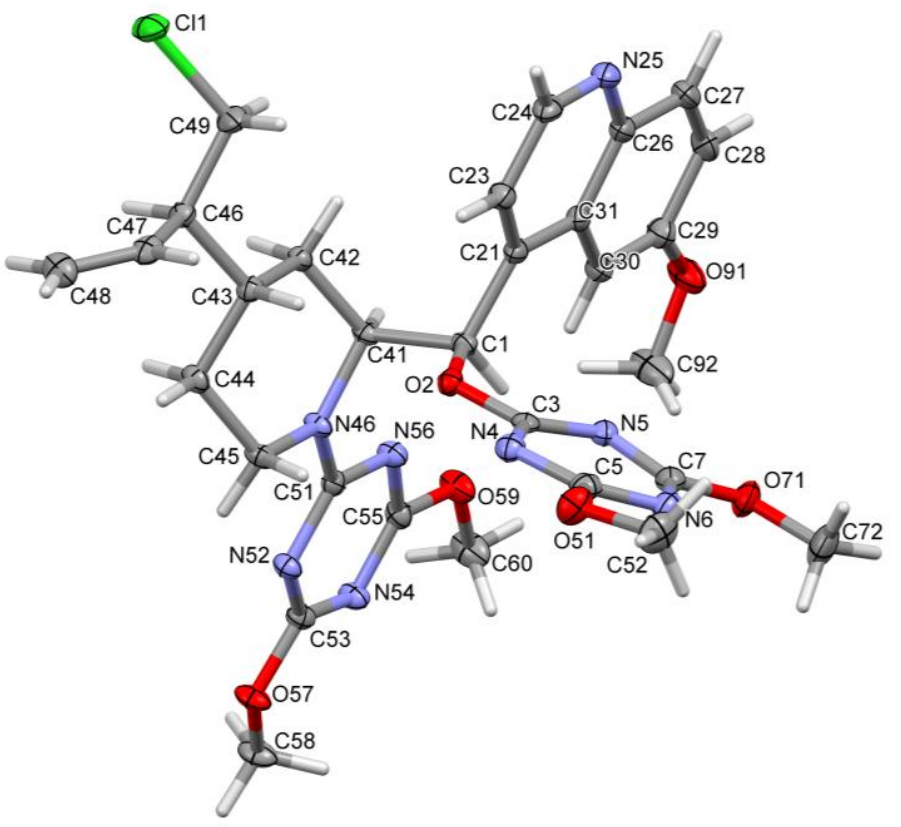

Figure 1. The molecular structure of compound $\mathbf{5}$, showing the atom-labelling schemes. Displacement ellipsoids are drawn at the $50 \%$ probability level except $\mathrm{H}$ atoms.

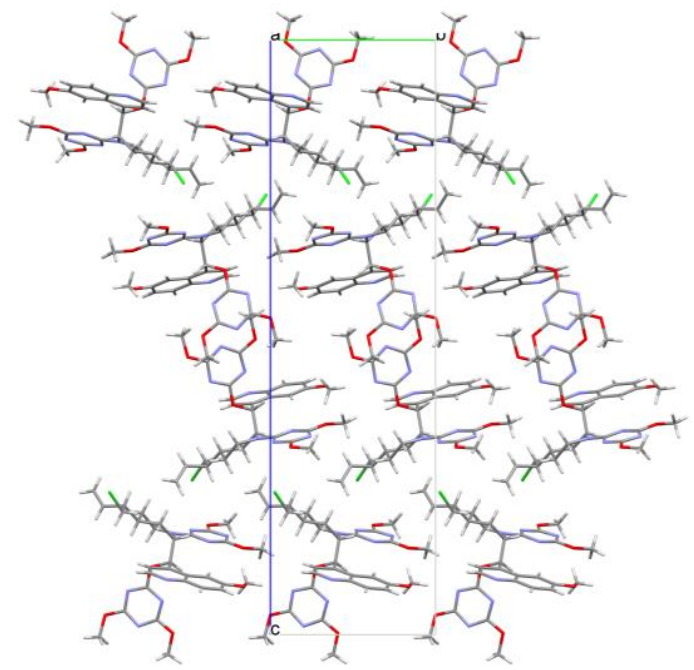

Figure 2. Packing of compound 5 in the crystal lattice. 
Table 1. Hydrogen-bond geometry $\left(\AA{ }^{\circ}{ }^{\circ}\right)$ for structure compound 5

\begin{tabular}{|c|c|c|c|c|}
\hline$D-\mathrm{H} \cdots A$ & $D-\mathrm{H}$ & $\mathrm{H} \cdots A$ & $D \cdots A$ & $D-H \cdots A$ \\
\hline $\mathrm{C} 41-\mathrm{H} 41 \cdots \mathrm{O} 57^{\mathrm{i}}$ & 0.98 & 2.55 & $3.377(2)$ & 142 \\
\hline $\mathrm{C} 52-\mathrm{H} 52 \mathrm{C} \cdots \mathrm{O}{ }^{\mathrm{iii}}$ & 0.96 & 2.46 & $3.260(3)$ & 140 \\
\hline $\mathrm{C} 72-\mathrm{H} 72 B \cdots O 91^{\mathrm{iv}}$ & 0.96 & 2.65 & $3.572(3)$ & 161 \\
\hline 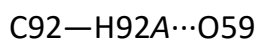 & 0.96 & 2.50 & 3.257 (3) & 135 \\
\hline $\mathrm{C} 92-\mathrm{H} 92 \mathrm{C} \cdots \mathrm{N} 4^{v}$ & 0.96 & 2.65 & $3.538(2)$ & 154 \\
\hline
\end{tabular}

Symmetry codes: (i) $x-1, y, z$; (ii) $-x, y+1 / 2,-z+3 / 2$; (iii) $x+1 / 2,-y+1 / 2,-z+2$; (iv) $x+1 / 2$, $-y+3 / 2,-z+2 ;$ (v) $x, y+1, z$.

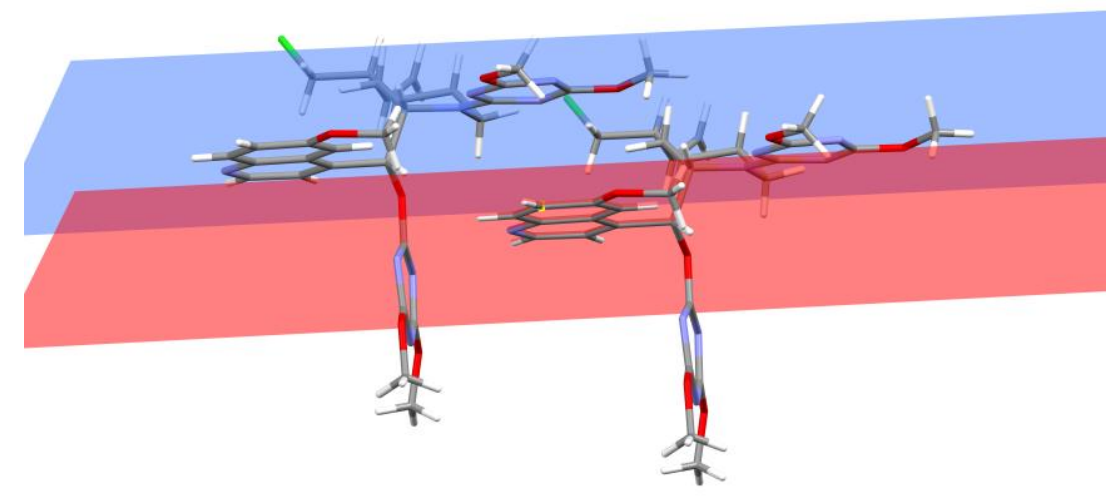

Figure 3. Stacking interactions of compound $\mathbf{5}$ in the crystal structure.

\section{Spectroscopic studies}

${ }^{1} \mathrm{H}$ NMR spectrum of isolated product (Figure 4) implies the presence of methoxyquinoline and two methoxytriazine fragments. ${ }^{10}$ 


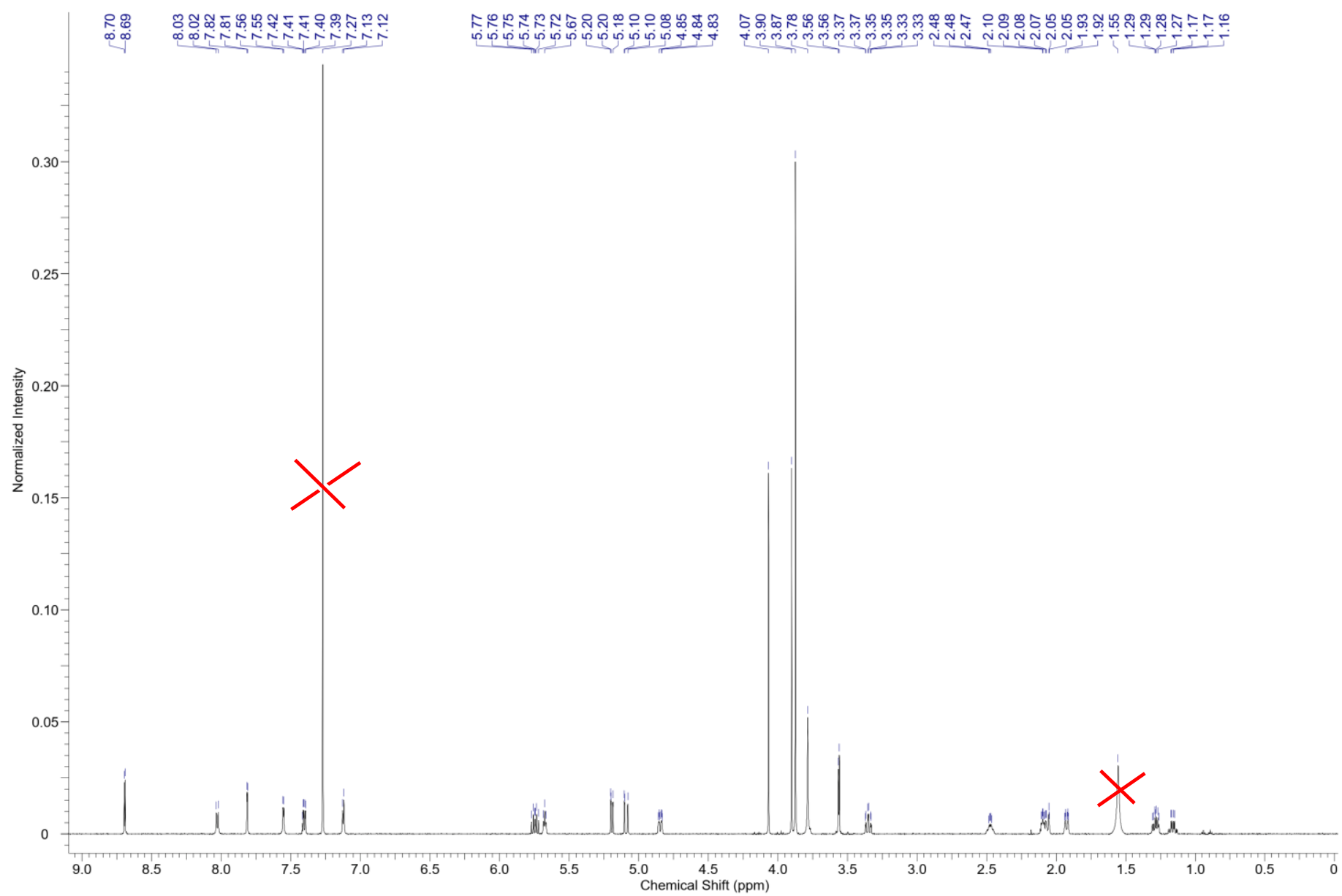

Figure 4. ${ }^{1} \mathrm{H}$ NMR spectrum of the main product 5 formed in the reaction of quinine with CDMT (2). Residual $\mathrm{CDCl}_{3}$ and $\mathrm{H}_{2} \mathrm{O}$ signals marked with a red cross.

In the ${ }^{1} \mathrm{H}$ NMR spectrum of product 5 (Figure 4), four groups of signals were identified. In the region typical of aromatic hydrogens 7.00-8.75 ppm, five doublets at $8.69(1 \mathrm{H}), 8.03(1 \mathrm{H}), 7.81(1 \mathrm{H}), 7.55(1 \mathrm{H})$, and $7.40(1 \mathrm{H}) \mathrm{ppm}$ were attributed to methoxyquinoline fragment of 1 . The sixth doublet at $7.12 \mathrm{ppm}$ was correlated on HSQC spectrum with $\mathrm{C} 1$ methine carbon at $76 \mathrm{ppm}$ (see Figure 5). In the native quinine molecule (1), this signal is observed at $1 \mathrm{ppm}$ higher field. The $1 \mathrm{ppm}$ lower field shift could be caused by de-shielding effect of the aromatic triazine ring located in the close proximity of $\mathrm{H}-\mathrm{C} 1$ methine proton after its reaction with bridgehead aliphatic nitrogen. 


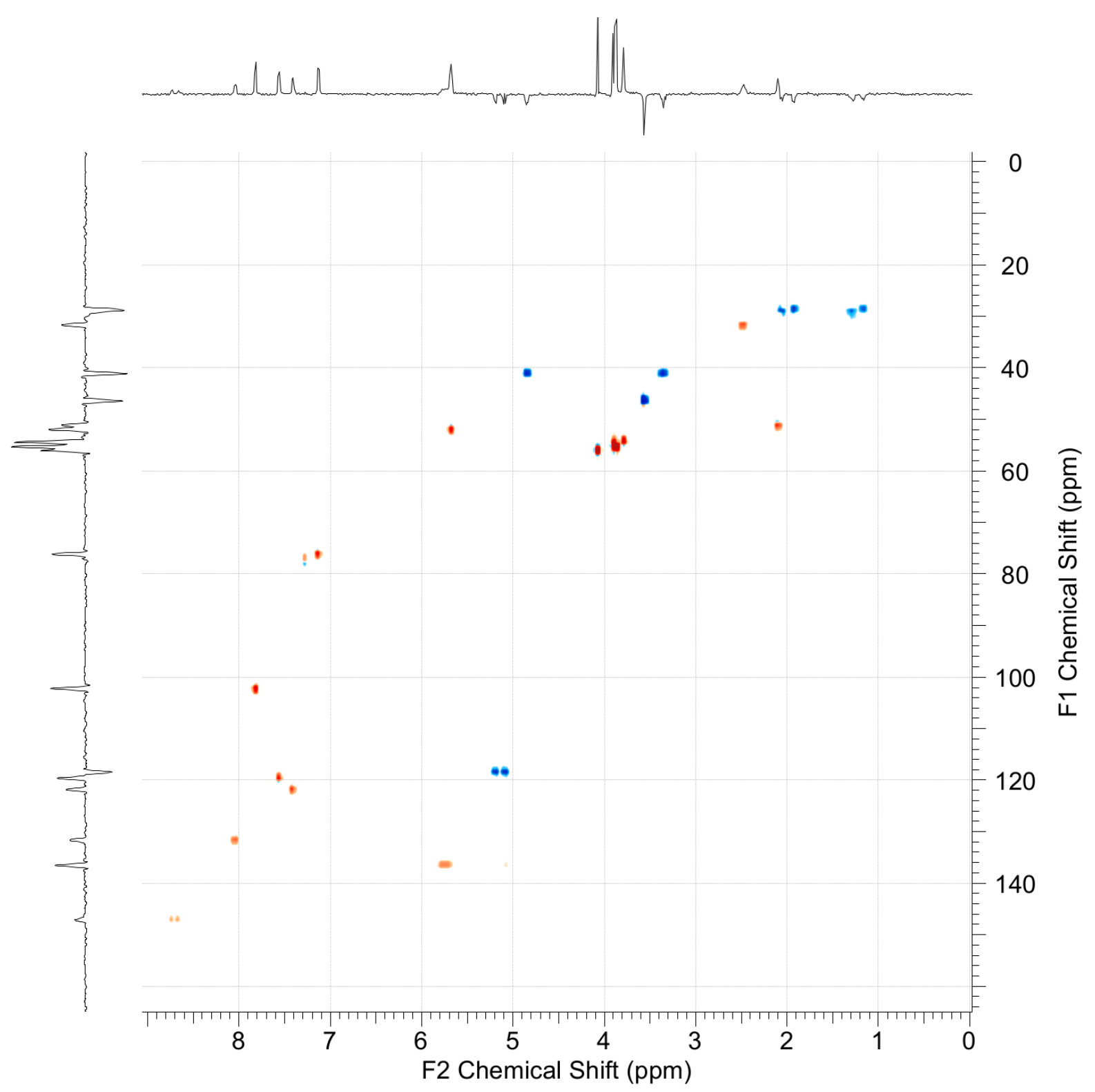

Figure 5. ${ }^{1} \mathrm{H}_{-}^{13} \mathrm{C} \mathrm{HSQC}$ spectrum in $\mathrm{CDCl}_{3}$ of the main product 5 formed in the reaction of quinine with $\mathrm{CDMT}$ (2).

The next group of signals is located at 5.00-5.80 ppm. Two protons at 5.09 and $5.19 \mathrm{ppm}$ are attached to $s p^{2}$ carbon $\mathrm{C} 48$ observed in HSQC spectrum at $118.3 \mathrm{ppm}$, characteristic of $\mathrm{C}=\mathrm{CH}_{2}$ fragment. They are coupled with a $1 \mathrm{H}$ multiplet similar to the double triplet at $5.75 \mathrm{ppm}$. The coupling constants of the doublets at 5.09 and $5.19 \mathrm{ppm}$ are 17.17 and $10.12 \mathrm{~Hz}$, respectively, which suggests their assignment to $-\mathrm{CH}=\mathrm{CH}_{2}$ fragment.

The blurred $1 \mathrm{H}$ triplet at $5.67 \mathrm{ppm}$ correlates with the $\mathrm{C} 41 s p^{3}$ carbon $51.9 \mathrm{ppm}$. Its down-field shift suggests attachment to the strongly electronegative atom and additionally the de-shielding effects caused by the presence of the aromatic ring. It is coupled with three other protons, two of them with similar coupling constants and according to the COSY spectrum, they are two $\mathrm{H}-\mathrm{C} 42$ methylene protons 1.27 and 2.05 ppm and $\mathrm{H}-\mathrm{C} 1$ methine proton $7.12 \mathrm{ppm}$. Therefore, this could be the proton of methine group $\mathrm{H}-\mathrm{C} 41$ in the ring, attached to the $\mathrm{N}$ atom and to the $\mathrm{H}-\mathrm{C} 1$ hydroxymethyl group.

The group of signals in the range $3.30-4.90 \mathrm{ppm}$ is fairly diversified. The most intensive were attributed to the five methoxy group. Two of them at $3.87 \mathrm{ppm}$ were magnetically equivalent and were representative of 
the free rotating 4,6-dimethoxy-1,3,5-triazin-2-yl fragment linked via oxygen ( $\mathrm{H}-\mathrm{C} 52$ and $\mathrm{H}-\mathrm{C} 72)$. Two nonequivalent methoxy groups at 3.90 and $4.07 \mathrm{ppm}$ are typical of the presence of the second 4,6-dimethoxy1,3,5-triazin-2-yl fragment ( $\mathrm{H}-\mathrm{C5} 8$ and $\mathrm{H}-\mathrm{C} 60)$. In this case, non-equivalence can result from the limited rotational freedom triazine ring caused by its coupling with the quinine frame possible via nitrogen atom. The undoubtedly documented incorporation of two triazinyl rings raise the question of where they are attached. Relatively undisturbed chemical shifts of the aromatic quinoline fragment, but strongly modified shifts of aliphatic hydrogens suggest the attachment of CDMT to nitrogen in the bridgehead position of quinine and to the hydroxyl group. This assumption is unexpected, because until now a faster reaction of CDMT with aromatic nitrogen rather than with more sterically hindered tertiary nitrogen attached to the aliphatic frame or to the less nucleophilic hydroxyl group has been observed in all cases. ${ }^{11,12}$

The chemical shift to $3.78 \mathrm{ppm}$ of protons of fifths methoxy group H-C92 was typical of the substituent at C29 position in the quinoline ring system.

According to HSQC spectrum, $1 \mathrm{H}$ broad doublet at $4.85 \mathrm{ppm}$ and $1 \mathrm{H}$ double triplet at $3.34 \mathrm{ppm}$ are attached to the same methylene carbon identified at $41.1 \mathrm{ppm}$. The double triplet multiplicity suggests the presence of three protons in the neighborhood with two of them as equivalents. The diversified, downfield shift of signals of this methylene hydrogens suggests their location in the ring C45 and close proximity of the strongly electronegative nitrogen atom N46.

The $2 \mathrm{H}$ doublet at $3.56 \mathrm{ppm}$ is coupled with multiplet at $2.09 \mathrm{ppm}$ and correlates with methylene carbon $46.4 \mathrm{ppm}$. The equivalence of both protons and their downfield shift suggest the location in the carbon chain with electronegative heteroatom in their neighborhood $>\mathrm{CH}-\mathrm{CH}_{2}-\mathrm{X}$ C49. This means that the bicyclic quinuclidine system was selectively opened by splitting N46-C49 bond of the fragment with the attached vinyl group but not the $-\mathrm{CH}_{2}-\mathrm{CH}_{2}$ - one.

Multiplets in the region 1.20-2.49 ppm confirm the presence of six different aliphatic protons. Protons 1.17 and 1.92 ppm correlate to methylene carbon 28.6 ppm C44 and protons 1.27 ppm H-C42 and 2.05 ppm $\mathrm{H}-\mathrm{C} 42$ correlate to methylene carbon $29.0 \mathrm{ppm}$. The diversified chemical shift of methylene protons may result from limited conformational freedom and strongly suggests their incorporation into the saturated ring system.

The comparison with ${ }^{13} \mathrm{C}$ - and DEPT-135 spectra of two additional multiplets of $\mathrm{C}-\mathrm{H}$ groups at $2.09 \mathrm{ppm} \mathrm{H}$ C46 and 2.46 ppm H-C43 confirmed their attachment to two different methine carbons at 51.2 ppm C46 and 31.7 ppm C43, respectively. Moreover, multiplet 2.09 ppm H-C46 is coupled with methylene proton $3.56 \mathrm{ppm}$ $\mathrm{H}-\mathrm{C} 49$ suggesting the location of them both in the native quinine molecule in the bridge of the quinuclidine fragment bearing a vinyl substituent.

The NMR data presented above made it possible to correlate structural fragments of product 5 with ${ }^{1} \mathrm{H}$ and ${ }^{13} \mathrm{C}$ NMR signals as shown in Table 2.

The occurrence of two different DMT substituents in product $\mathbf{5}$ was further supported by MS studies. In $\mathrm{ESI}^{+}$mode (Figure 6), two molecular ions $\mathrm{M}+1$ were observed at 639.8; 641.8 with intensities of signals 3:1 characteristic of the presence of the chlorine atom in the molecule. Their degradation pathway gave two pairs of the most abundant ions 482.6; 484.6 and $311.5 ; 315.5$ with a characteristic $3: 1$ intensity. The first pair involved splitting of 157.2 ion assigned to $\mathrm{C}_{5} \mathrm{H}_{7} \mathrm{~N}_{3} \mathrm{O}_{3}$ of 2-hydroxy-4,6-dimethoxy-1,3,5-triazine or its isomer. The second pair was formed by splitting 171.1 ion $\left(\mathrm{C}_{6} \mathrm{H}_{12} \mathrm{~N}_{4} \mathrm{O}_{2}\right)$, which could be assigned to protonated 2methylamino-4,6-dimethoxy-1,3,5-triazine. ${ }^{10}$ 
Table 2. Collected ${ }^{1} \mathrm{H}$ and ${ }^{13} \mathrm{C}$ MNR chemical shifts and their correlation with the structure of main product 5 formed in the reaction of CDMT (2) with quinine (1). (DMT = 2,4-dimethoxy-1,3,5-triazin-2-yl)

\begin{tabular}{|c|c|c|c|}
\hline position & group & ${ }^{1} \mathrm{H} N M R$ & ${ }^{13} \mathrm{C}$ NMR \\
\hline $\mathrm{C} 42$ & $-\mathrm{CH}_{2-}^{-}$ & $\begin{array}{c}1.27\left(\mathrm{dt}, 1 \mathrm{H}, J_{1} 13.5 \mathrm{~Hz}, J_{2} 5.9 \mathrm{~Hz},\right) \\
2.03-2.08(\mathrm{~m}, 1 \mathrm{H})\end{array}$ & 29.0 \\
\hline $\mathrm{C} 44$ & $-\mathrm{CH}_{2-}^{-}$ & $\begin{array}{c}1.17\left(\mathrm{dq}, 1 \mathrm{H}, J_{1} 12.8 \mathrm{~Hz}, J_{2} 4.8 \mathrm{~Hz}\right) \\
1.92(\mathrm{~d}, 1 \mathrm{H}, J 12.8 \mathrm{~Hz})\end{array}$ & 28.6 \\
\hline $\mathrm{C} 43$ & $-\mathrm{CH}<$ & 2.43-2.51 (m, 1H) & 31.7 \\
\hline $\mathrm{C} 46$ & $-\mathrm{CH}<$ & $2.08-2.12(\mathrm{~m}, 1 \mathrm{H})$ & 51.2 \\
\hline C49 & $-\mathrm{CH}_{2}-\mathrm{Cl}$ & $3.56(\mathrm{~d}, 2 \mathrm{H}, J 5.7 \mathrm{~Hz})$ & 46.4 \\
\hline $\mathrm{C} 45$ & $-\mathrm{CH}_{2-}^{-}$ & $\begin{array}{c}3.34\left(\mathrm{dt}, 1 \mathrm{H}, J_{1} 13.4 \mathrm{~Hz}, J_{2} 3.1 \mathrm{~Hz}\right) \\
4.85(\mathrm{bd}, 1 \mathrm{H}, J 13.5 \mathrm{~Hz})\end{array}$ & 41.1 \\
\hline C92 & $\mathrm{CH}_{3}-\mathrm{O}$ & $3.78(\mathrm{~s}, 3 \mathrm{H})$ & - \\
\hline $\mathrm{C} 52+\mathrm{C} 72$ & $2 \mathrm{CH}_{3}-\mathrm{O}$ & $3.87(\mathrm{~s}, 6 \mathrm{H})$ & - \\
\hline C58 & $\mathrm{CH}_{3}-\mathrm{O}$ & $3.90(\mathrm{~s}, 3 \mathrm{H})$ & - \\
\hline $\mathrm{C} 60$ & $\mathrm{CH}_{3}-\mathrm{O}$ & $4.07(\mathrm{~s}, 3 \mathrm{H})$ & - \\
\hline C41 & $-\mathrm{CH}<$ & $5.67(t, 1 \mathrm{H}, J 6.4 \mathrm{~Hz})$ & 51.9 \\
\hline $\mathrm{C} 1$ & $>\mathrm{CH}-\mathrm{O}-\mathrm{DMT}$ & $7.12(\mathrm{~d}, 1 \mathrm{H}, J 6.5 \mathrm{~Hz})$ & 76.0 \\
\hline $\mathrm{C} 47$ & $=\mathrm{CH}-$ & $5.75\left(\mathrm{dt}, 1 \mathrm{H}, J_{1} 17.2 \mathrm{~Hz}, J_{2} 10.1 \mathrm{~Hz}\right)$ & 136.0 \\
\hline \multirow{2}{*}{$\mathrm{C} 48$} & $\mathrm{H}$ cis $\mathrm{H}$ to $\mathrm{C} 5$ & $5.19(\mathrm{~d}, 1 \mathrm{H}, J 10.1 \mathrm{~Hz})$ & 118.3 \\
\hline & $\mathrm{H}$ trans to $\mathrm{C} 5$ & $5.09(\mathrm{~d}, 1 \mathrm{H}, J 17.2 \mathrm{~Hz})$ & \\
\hline $\mathrm{C} 24$ & $\mathrm{H}-\mathrm{Ar}$ & $8.69(\mathrm{~d}, 1 \mathrm{H}, \mathrm{J} 4.6 \mathrm{~Hz})$ & 147.0 \\
\hline $\mathrm{C} 23$ & $\mathrm{H}-\mathrm{Ar}$ & $7.55(\mathrm{~d}, 1 \mathrm{H}, \mathrm{J} 4.6 \mathrm{~Hz})$ & 119.6 \\
\hline C30 & $\mathrm{H}-\mathrm{Ar}$ & $7.81(\mathrm{~d}, 1 \mathrm{H}, J 2.2 \mathrm{~Hz})$ & 102.4 \\
\hline $\mathrm{C} 28$ & $\mathrm{H}-\mathrm{Ar}$ & $7.40\left(\mathrm{dd}, 1 \mathrm{H}, J_{1} 9.2 \mathrm{~Hz}, J_{2} 2.2 \mathrm{~Hz}\right)$ & 122.0 \\
\hline $\mathrm{C} 27$ & $\mathrm{H}-\mathrm{Ar}$ & $8.03(\mathrm{~d}, 1 \mathrm{H}, J 9.2 \mathrm{~Hz})$ & 131.6 \\
\hline
\end{tabular}




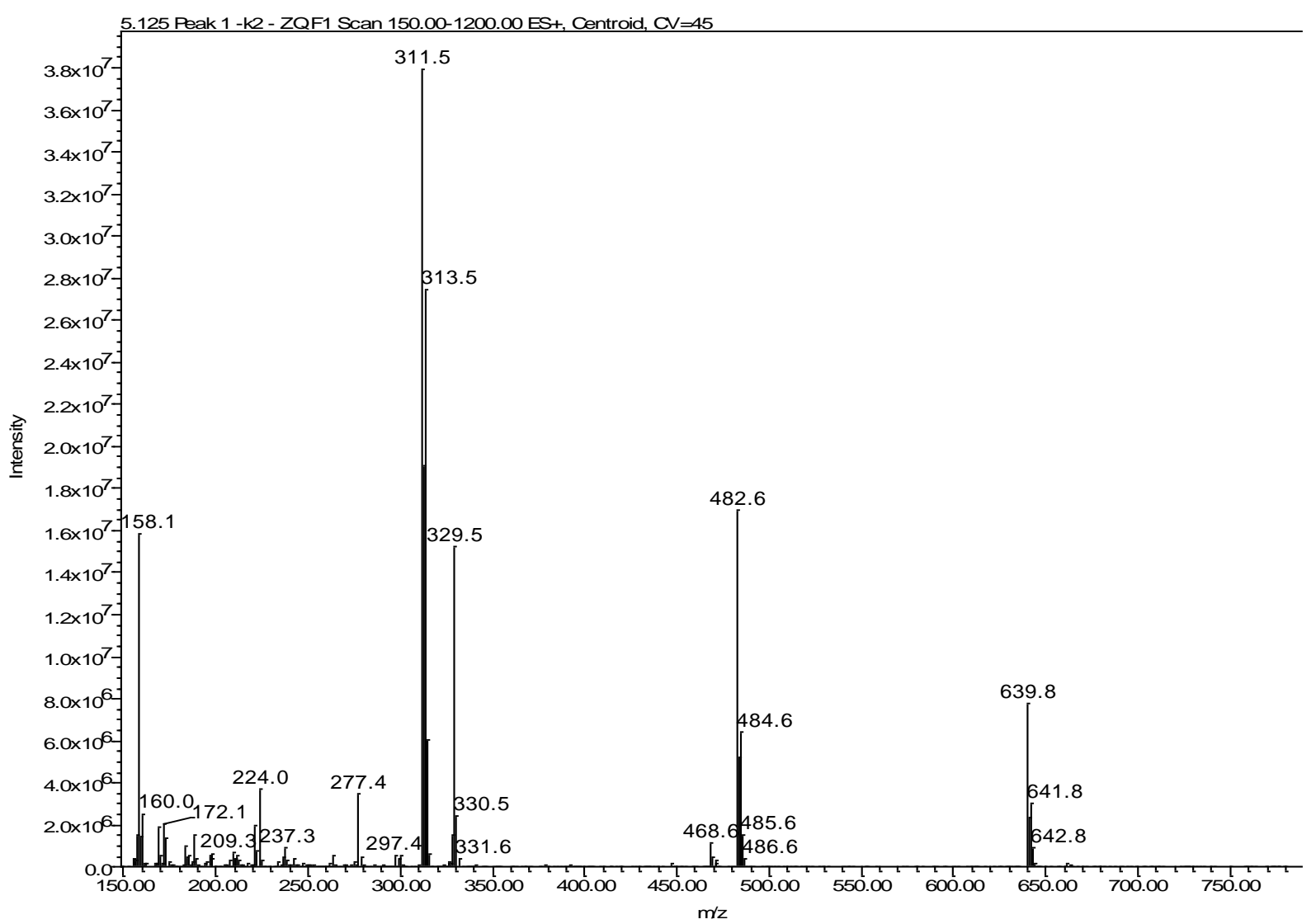

Figure 6. Mass spectrum $\left(\mathrm{ESI}^{+}\right)$of the main product 5 formed in the reaction of quinine with $\mathrm{CDMT}(\mathbf{2})$ isolated after crystallization from ethyl acetate / $n$-heptane.

\section{The reaction of quinine tetrafluoroborate (6) with 2-chloro-4,6-dimethoxy-1,3,5-triazine (2)}

Previous studies revealed that quaternization of tertiary amines in the reaction with CDMT (2) is very sensitive towards steric hindrance. ${ }^{10}$ Careful observations of the progress of the reaction of quinine with CDMT (2) suggested relatively fast consumption of CDMT (2) in the preliminary phase of the reaction accompanied by the formation of the non-identified intermediate followed by its slow decay. Also, the presence of traces of CDMT (2) was detected in the reacting mixture up to $48 \mathrm{~h}$, although in the quinine molecule there are three nucleophilic centers potentially prone to reaction with CDMT (2). To identify the intermediate and prevent its further transformations, the nucleophilic chlorine anion was substituted with the non-nucleophilic tetrafluoroborate counter ion ${ }^{6}$ as depicted below in Scheme 2.

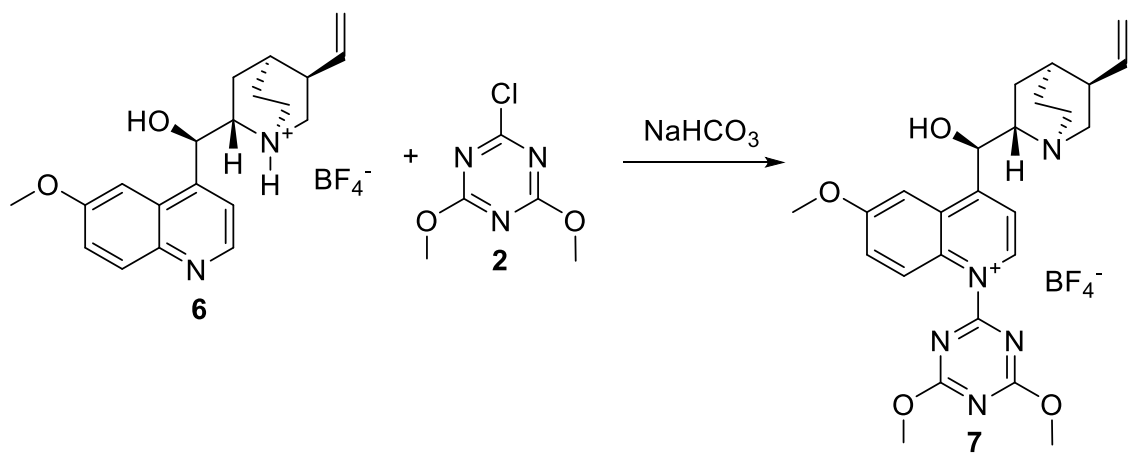

Scheme 2. Synthesis of quinine derivative 7 in the reaction of quinine tetrafluoroborate (6) with CDMT (2). 
In the ${ }^{1} \mathrm{H}$ NMR spectrum of isolated crude product 7, both methoxy substituents of the triazine ring are equivalent and a down-field chemical shift from $8.70 \mathrm{ppm}$ was observed for proton $\mathrm{N}-\mathrm{CH}$ in native quinine to $9.25 \mathrm{ppm}$, expected for the $\mathrm{N}^{+}-\mathrm{CH}$ quinoline fragment in 7 . This strongly suggests the attachment of the DMT fragment to aromatic nitrogen in the quinoline ring. Thus, it becomes obvious that the presence of nucleophilic chloride is crucial for the reaction pathway leading to product $\mathbf{5}$. Two diverse reaction pathways could be rationalized assuming the reversibility of the first step in the reaction between quinine and CDMT (2), leading to $\mathbf{4}$, which is an equivalent of $\mathbf{7}$ with a chloride substituting tetrafluoroborate (see Scheme 3 ).

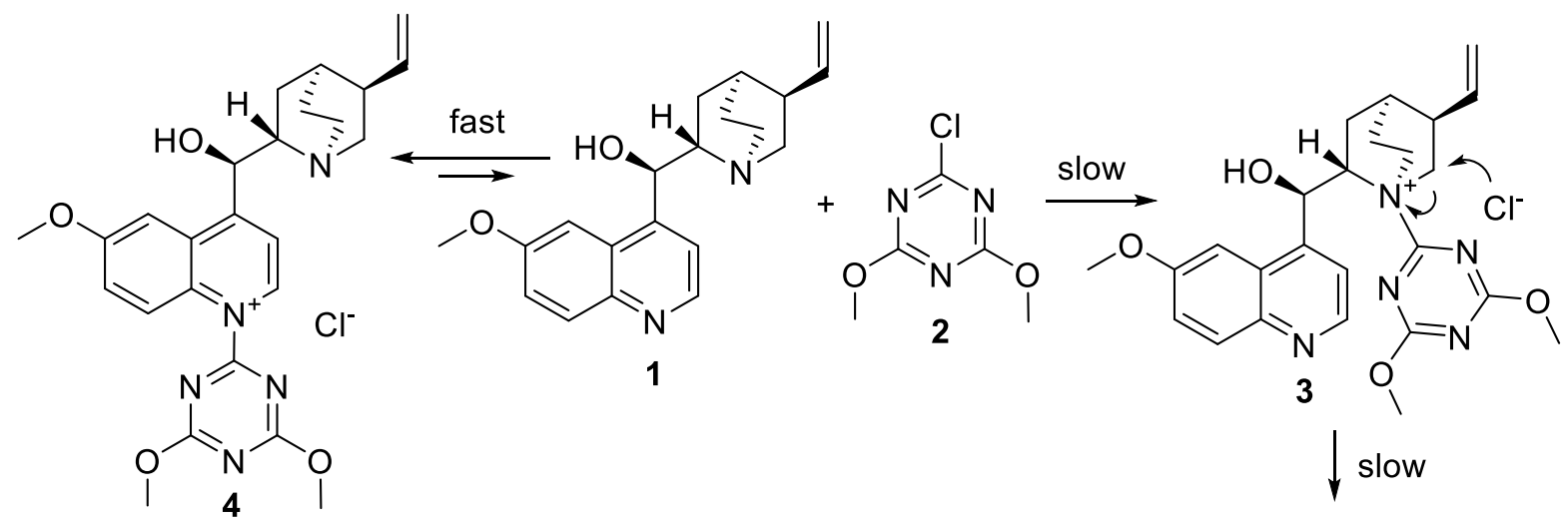<smiles>C=C[C@H](CCl)C1CCN(c2nc(OC)nc(OC)n2)[C@H]([C@H](Oc2nc(OC)nc(OC)n2)c2cnc3ccc(OC)cc3c2)C1</smiles><smiles>C=C[C@H](CCl)C1CCN(c2nc(OC)nc(OC)n2)C(C)(C(C)(C)OCCc2nc(Cl)nc(OC)n2)C1</smiles>

Scheme 3. Postulated transformation path leading to 5.

Most CDMT (2) is relatively rapidly consumed in the reaction with quinine, although a reverse process of $\mathrm{S}_{\mathrm{N}} \mathrm{Ar}$ substitution involving quinolinium $\mathbf{4}$ and nucleophilic chloride generates minute amounts of CDMT, detected by color NBP test ${ }^{12}$ in the reacting mixture for up to $48 \mathrm{~h}$. The occurrence of CDMT (2) for the prolonged time supports the slow process involving the bridgehead aliphatic nitrogen atom of the quinuclidine fragment followed by the irreversible step of the nucleophilic attack of the chloride anion opening the bicyclic system with the formation of $\mathbf{8}$. The presence of the basic triazine ring in the close proximity of the hydroxylic group in $\mathbf{8}$ strongly promotes its deprotonation and reaction with CDMT (2), yielding $\mathbf{5}$ as the final product of the transformation.

\section{Conclusions}

This new transformation of quinine retains intact most of the stereogenic centers of the alkaloid molecule. The reaction with the bicyclic system with the bridgehead nitrogen atom resembles the von Braun reaction ${ }^{13}$ involving cyanogen chloride. Nevertheless, the important advantage of the new procedure over the von Braun 
process is the easy modification of the triazine component paving the way to the plethora of new chiral products even from the single tertiary amine component. The scope and limitations of the above procedure are under investigation. Preliminary work support its versatility in the synthesis of pharmaceutically active compounds. ${ }^{14-16}$ While other potential applications include use as new chiral auxiliaries ${ }^{17}$ building blocks, and pesticides ${ }^{18}$ etc.

\section{Experimental Section}

General. TLC plates: Silicagel, Merck 254. Preparative column chromatography: Silicagel 60, Merck 240-600 mesh. HPLC: Waters 600S, gradient system, detector Waters 2489 UV/VIS; column Vydac C18 $(250 \times 4.6 \mathrm{~mm})$. NMR studies were performed using Bruker $700 \mathrm{MHz}$ Ultrashield Plus with ACD/Labs: ACD/ChemSketch and ACD/NMR Processor software and/or Bruker Avance DPX 250 (250 MHz spectrometer. IR spectra were recorded using IR ALFA Bruker spectrometer. Dyfraktometric measurements were performed on Bruker Nonius Smart APEX-II CCD with SHELXL from SHELX-97 package programme.

Reaction of quinine (1) with 2-chloro-4,6-dimethoxy-1,3,5-triazine (2). Quinine (1) (1.62 g, $5 \mathrm{mmol})$ and CDMT (2) $(880 \mathrm{mg}, 5 \mathrm{mmol})$ were dissolved in dichloromethane $(10 \mathrm{~mL})$ and stirred for $24 \mathrm{~h}$ at room temp., then heated under reflux for additional $24 \mathrm{~h}$. After evaporation to dryness, a crude product was obtained as a colorless solid $(2.50 \mathrm{~g})$. TLC analysis (hexane/acetone, $2: 1$ ) revealed visible at UV $=254 \mathrm{~nm}$ three spots $R_{\mathrm{f}}=$ 0.30 (major); $R_{\mathrm{f}}=0.15$ and $R_{\mathrm{f}}=0.00$ and additionally two spots visible at $366 \mathrm{~nm}$ at $R_{\mathrm{f}}=0.27$ and $R_{\mathrm{f}}=0.12$. A part of the crude product $(1.00 \mathrm{~g})$ was dissolved in acetone, adsorbed onto silica gel, and loaded onto a column filled with $80 \mathrm{~mL}$ silica gel and eluted with hexane/acetone. The second fraction was collected and concentrated to dryness to afford a colorless solid (480 mg; yield $75 \%$ as calculated on CDMT). Its homogeneity profile is presented in supporting material (Figure 1, upper panel a and b). After recrystallization, colorless needles were obtained, $\mathrm{mp} 84-88^{\circ} \mathrm{C}$ ( $n$-heptane/EtOAc); IR: 2943, 2867, 1620, 1553, 1352, 1259, 1131, 1104, 1025, $816\left[\mathrm{~cm}^{-1}\right] ;{ }^{1} \mathrm{H}$ NMR $\left(700 \mathrm{MHz}, \mathrm{CDCl}_{3}\right) \delta_{\mathrm{H}} 1.17\left(\mathrm{dq}, 1 \mathrm{H}, J_{1} 12.8 \mathrm{~Hz}, J_{2} 4.8 \mathrm{~Hz}\right), 1.27\left(\mathrm{dt}, 1 \mathrm{H}, J_{1}\right.$ $\left.13.5 \mathrm{~Hz}, J_{2} 5.9 \mathrm{~Hz}\right), 1.92(\mathrm{~d}, 1 \mathrm{H}, J 12.8 \mathrm{~Hz}), 2.03-2.08(\mathrm{~m}, 1 \mathrm{H}), 2.08-2.12(\mathrm{~m}, 1 \mathrm{H}), 2.43-2.51(\mathrm{~m}, 1 \mathrm{H}), 3.34(\mathrm{dt}, 1 \mathrm{H}$, $\left.J_{1} 13.4 \mathrm{~Hz}, J_{2} 3.1 \mathrm{~Hz}\right), 3.56(\mathrm{~d}, 2 \mathrm{H}, J 5.7 \mathrm{~Hz}), 3.78(\mathrm{~s}, 3 \mathrm{H}), 3.87(\mathrm{~s}, 6 \mathrm{H}), 3.90(\mathrm{~s}, 3 \mathrm{H}), 4.07(\mathrm{~s}, 3 \mathrm{H}), 4.87(\mathrm{bd}, 1 \mathrm{H}, J$ $13.5 \mathrm{~Hz}), 5.09(\mathrm{~d}, 1 \mathrm{H}, J 17.2 \mathrm{~Hz}), 5.19(\mathrm{~d}, 1 \mathrm{H}, J 10.1 \mathrm{~Hz}), 5.67(\mathrm{t}, 1 \mathrm{H}, J 6.4 \mathrm{~Hz}), 5.75\left(\mathrm{dt}, 1 \mathrm{H}, J_{1} 17.2 \mathrm{~Hz}, J_{2} 10.1 \mathrm{~Hz}\right)$, $7.12\left(\mathrm{~d}, 1 \mathrm{H}, J 6.5 \mathrm{~Hz}\right.$ ), 7.40 (dd, $\left.1 \mathrm{H}, J_{1} 9.2 \mathrm{~Hz}, J_{2} 2.2 \mathrm{~Hz}\right), 7.55(\mathrm{~d}, 1 \mathrm{H}, J 4.6 \mathrm{~Hz}), 7.81(\mathrm{~d}, 1 \mathrm{H}, J 2.2 \mathrm{~Hz}), 8.03(\mathrm{~d}, 1 \mathrm{H}, J$ $9.2 \mathrm{~Hz}), 8.69(1 \mathrm{H}, \mathrm{d}, J 4.6 \mathrm{~Hz}) ;{ }^{13} \mathrm{C} \mathrm{NMR}\left(176 \mathrm{MHz}, \mathrm{CDCl}_{3}\right) \delta_{\mathrm{C}} 28.6\left(\mathrm{CH}_{2} ; \mathrm{C} 44\right), 29.0\left(\mathrm{CH}_{2} ; \mathrm{C} 42\right), 31.7(\mathrm{CH} ; \mathrm{C} 43)$, $41.1\left(\mathrm{CH}_{2} ; \mathrm{C} 45\right), 46.4\left(\mathrm{CH}_{2}-\mathrm{Cl} ; \mathrm{C} 49\right), 51.2(\mathrm{CH} ; \mathrm{C} 44), 51.9(\mathrm{CH} ; \mathrm{C} 41), 54.1\left(\mathrm{CH}_{3}-\mathrm{O} ; \mathrm{C} 92\right), 54.2\left(\mathrm{CH}_{3}-\mathrm{O} ; \mathrm{C} 53, \mathrm{C} 72\right)$, $55.2\left(\mathrm{CH}_{3}-\mathrm{O}\right), 56.0\left(\mathrm{CH}_{3}-\mathrm{O}\right), 76.0(\mathrm{CH} ; \mathrm{C} 1), 102.4\left(\mathrm{C}_{\mathrm{ar}} ; \mathrm{C} 30\right), 118.3\left(\mathrm{CH}_{2} ; \mathrm{C} 48\right), 119.6\left(\mathrm{C}_{\mathrm{ar}}, \mathrm{C} 23\right), 121.6(\mathrm{C} 21), 122.0$ $\left(\mathrm{C}_{\mathrm{ar}}, \mathrm{C} 28\right), 128.3\left(\mathrm{C}_{\mathrm{ar}}\right), 131.6\left(\mathrm{C}_{\mathrm{ar}}, \mathrm{C} 27\right), 136.0(=\mathrm{CH}, \mathrm{C} 47), 147.0\left(\mathrm{C}_{\mathrm{ar}}, \mathrm{C} 24\right), 147.3\left(\mathrm{C}_{\mathrm{ar}}\right), 158.4\left(\mathrm{C}_{\mathrm{ar}}\right), 167.0\left(\mathrm{C}_{\mathrm{ar}}-\mathrm{N}_{\mathrm{ar}}\right)$, $172.1\left(\mathrm{C}_{\mathrm{ar}}-\mathrm{N}_{\mathrm{ar}}\right), 172.5 ;\left(\mathrm{C}_{\mathrm{ar}}-\mathrm{N}_{\mathrm{ar}}\right), 173.4\left(\mathrm{C}_{\mathrm{ar}}-\mathrm{N}_{\mathrm{ar}}\right) ; \mathrm{MS}: \mathrm{M}+1=639.8 ; 641.8(3: 1)\left(\mathrm{ESI}^{+}\right)$.

The reaction of quinine tetrafluoroborate (6) with CDMT (2) Quinine (40.54 g, $100 \mathrm{mM})$ and ammonium tetrafluoroborate $(10.56 \mathrm{~g}, 100 \mathrm{mM})$ were dissolved in acetonitrile $(400 \mathrm{~mL})$ and heated under reflux until all ammonia evolution was ceased. The obtained clear solution was stirred and cooled to $0{ }^{\circ} \mathrm{C}$, then solid sodium bicarbonate $(16.80 \mathrm{~g}, 200 \mathrm{mM})$ was added. The slurry was treated with the solution of CDMT (2) (17.50 g, 100 $\mathrm{mM}$ ) in acetonitrile $\left(50 \mathrm{~mL}\right.$ ) and stirring was continued at $0-5{ }^{\circ} \mathrm{C}$ until all CDMT (2) was consumed (TLC control, mobile phase $100 \%$ dichloromethane, disappearing of spot $R_{\mathrm{f}}=0.6$, visualization by spraying with $0.5 \%$ solution of 4-(4'-nitrobenzyl)pyridine (NBP) in ethanol. ${ }^{18}$ The slurry was filtered. Filter cake was washed with 
acetonitrile $(3 \times 20 \mathrm{~mL})$. The filtrates were combined and evaporated under reduced pressure. The colorless oily residue was dried in vacuum desiccator in the presence of $\mathrm{P}_{2} \mathrm{O}_{5}$ and $\mathrm{KOH}$ to a constant weight yielding 7 (49.68 g, 85\%) in the form of colorless oil: ${ }^{1} \mathrm{H}$ NMR $\left(250 \mathrm{MHz}, \mathrm{CD}_{3} \mathrm{CN}\right) \delta_{\mathrm{H}} 1.39-2.39\left(\mathrm{~m}, 6 \mathrm{H}, \mathrm{CH}_{2}\right), 2.54-2.84(\mathrm{~m}$, $\left.2 \mathrm{H}, \mathrm{N}-\mathrm{CH}_{2}\right), 3.25-3.56\left(\mathrm{~m}, 3 \mathrm{H}, \mathrm{N}-\mathrm{CH}_{2}+\mathrm{N}-\mathrm{CH}\right), 3.89\left(\mathrm{~s}, 3 \mathrm{H}, \mathrm{O}-\mathrm{CH}_{3}\right), 4.02\left(\mathrm{~s}, 6 \mathrm{H}, \mathrm{OCH}_{3}\right), 4.99\left(\mathrm{dd}, 2 \mathrm{H}, J_{1} 17.0 \mathrm{~Hz}, J_{2}\right.$ $\left.9.0 \mathrm{~Hz}, \mathrm{CH}_{2}=\right), 5.44(\mathrm{~d}, 1 \mathrm{H}, J 8.0 \mathrm{~Hz}, \mathrm{O}-\mathrm{CH}), 5.85-5.92(\mathrm{~m}, 1 \mathrm{H},=\mathrm{CH}), 7.40-8.03\left(\mathrm{~m}, 4 \mathrm{H}, \mathrm{CH}_{\text {arom }}\right), 9.25(\mathrm{~d}, 1 \mathrm{H}, J 5.5$ $\left.\mathrm{Hz}, \mathrm{N}^{+}-\mathrm{CH}_{\text {arom }}\right)$; additional spectroscopic data was not recorded owing to the poor quality of the sample.

\section{Acknowledgements}

The authors thank the Lodz University of Technology for the financial support.

\section{Supplementary Material}

Analytical data of compound $\mathbf{5}$ available in supplementary material.

\section{References}

1. Kacprzak, K.; Gawronski, J. In Cinchona Alkaloids in Synthesis and Catalysis; Song, C. E. Ed.; Wiley, 2009, pp 421-469.

https://doi:10.1002/9783527628179

2. Hoffmann, H. M. R.; Frackenpohl, J. In Cinchona Alkaloids in Synthesis and Catalysis; Song, C. E. Ed.; Wiley, 2009, pp 359-418. https://doi:10.1002/9783527628179

3. Franz, M. H.; Röper, S.; Wartchow, R.; Hoffmann, H. M. R. Eur. J. Org. Chem. 2004, 21, 4293-4312. https://doi.org/10.1002/ejoc.200400294

4. Kolesińska, B.; Kamiński, Z. J. Org. Lett. 2009, 11, 765-768. https://doi.org/10.1021/ol802691x

5. Kolesińska, B.; Kasperowicz, K.; Sochacki, M.; Mazur, A.; Jankowski, S.; Kamiński, Z. J. Tetrahedron Lett. 2010, 51, 20-22. https://doi.org/10.1016/i.tetlet.2009.06.105

6. Kamiński, Z. J.; Kolesińska, B.; Kolesińska, J.; Sabatino, G.; Chelli, M.; Rovero, P.; Błaszczyk, M.; Główka, M. L.; Papini, A. M. J. Am. Chem. Soc. 2005, 127, 16912-16920. https://doi.org/10.1021/ja054260y

7. Sheldrick, G. M. Acta Crystallogr. A, 2008, 64, 112-122. https://doi.org/10.1107/S0108767307043930

8. Sheldrick, G. M. Acta Crystallogr. C, 2015, 71, 3-8. https://doi.org/10.1107/S2053229614024218

9. Macrae, C. F.; Edgington, P. R.; McCabe, P.; Pidcock, E.; Shields, G. P.; Taylor, R.; Towler, M.; van de Streek, J. J. Appl. Crystallogr. 2006, 39, 453-457. https://doi.org/10.1107/S0021889810042482 
10. Silverstein, R. M.; Webster, F. X.; Kiemle, D. J. In Spectrometric Identification of Organic Compounds, $7^{\text {th }}$ ed. J. Wiley, 2005.

11. Kolesinska, B.; Kaminski, Z. J. Polish J. Chem. 2008, 82, 2115-2123.

12. Kolesinska, B.; Rozniakowski, K. K.; Fraczyk, J.; Relich, I.; Papini, A. M.; Kaminski, Z. J. Eur. J. Org. Chem. 2015, 401-408. https://doi,org/10.1002/ejoc.201402862

13. von Braun, J.; K. Heider, K.; Müller, E. Chem. Ber. 1918, 51, 273-282. https://doi,org/10.1002/cber.19180510132

14. Fraczyk, J.; Kolesinska, B.; Swiontek, M.; Lipinski, W.; Drozdowska D.; Kaminski, Z. J. Anticancer Agents Med. Chem. 2016, 16, 1435-1444. https://doi.org/10.2174/1871520616666160204111430

15. Krętowski, R; Drozdowska, D.; Kolesińska, B.; Kamiński, Z. J.; Frączyk, J. Cechowska-Pasko, M. Invest. New Drugs 2019, 37, 984-993. https://doi.org/10.1007/s10637-018-0712-8

16. Wróbel, A.; Kolesińska, B.; Frączyk, J.; Kamiński, Z. J.; Tankiewicz-Kwedlo, A.; Hermanowicz, J.; Czarnomysy, R.; Maliszewski, D.; Drozdowska, D. Invest. New Drugs 2019, 38, 990-1002. https://doi.org/10.1007/s10637-019-00838-9

17. Kim, B.; Nakatsuji, M.; Mameda, T.; Kubota, T.; Fujita, M.; Sugimura, T.; Okamoto, Y. Bull. Chem. Soc. Jpn. 2020, 93, 163-175. https://doi.org/10.1246/bcsj.20190290

18. Che, Z.; Yang, J.; Sun, D.; Tian, Y.; Liu, S.; Lin, X.; Jiang, J.; Chen, G. Comb. Chem. High Throughput Screening 2020, 23, 111-118. https://doi.org//10.2174/1386207323666200120112714

19. Epstein, J.; Rosenthal, R. W.; Ess, R. J. Anal. Chem. 1955, 27, 1435-1439. https://doi.org/10.1021/ac60105a022 